\title{
PENGARUH ATTITUDE, SUBJECTIVE NORM, DAN PERCEIVED BEHAVIOR CONTROL TERHADAP PURCHASE INTENTION MAKANAN SEHAT DI CRUNCHAUS SURABAYA
}

\author{
Hanjaya Siaputra ${ }^{*}$, Enrico Isaac $^{2}$ \\ ${ }^{1,2}$ Program Manajemen Perhotelan, Universitas Kristen Petra \\ Jl. Siwalankerto 121-131, Surabaya \\ E-mail: ${ }^{1}$ tjunhan@petra.ac.id; ${ }^{2}$ enricoisaac44@yahoo.com \\ *Penulis korespondensi
}

\begin{abstract}
Abstrak
Penelitian ini bertujuan untuk mengetahui pengaruh attitude, subjective norm, dan perceived behavior control terhadap purchase intention makanan sehat di Crunchaus Surabaya. Penelitian ini dilakukan terhadap 205 responden, hasil penelitian menunjukkan bahwa attitude, subjective norm, dan perceived behavior control berpengaruh positif dan signifikan terhadap purchase intention makanan sehat di Crunchaus Surabaya. Variabel attitude merupakan variabel yang paling dominan terhadap purchase intention makanan sehat di Crunchaus Surabaya.
\end{abstract}

Kata kunci: Sikap, Norma Subjektif, Perceived Behavior Control, Minat Beli.

\section{Abstract}

This study aims to determine the effects of attitude, subjective norm, and perceived behavior control toward purchase intention of healthy food in Crunchaus Surabaya. This research was conducted on 205 respondents, the result of this study shows that attitude, subjective norm, and perceived behavior control have positive and significant influence toward purchase intention in Crunchaus Surabaya. Attitude is the most dominant variable toward purchase intention of healthy food in Crunchaus Surabaya.

Keywords: Attitude, Subjective Norm, Perceived Behavior Control, Purchase Intention.

\section{PENDAHULUAN}

Dengan berkembangnya dunia bisnis saat ini, konsumen dihadapkan dengan banyak keputusan dalam kehidupan sehari-hari. Konsumen tidak hanya harus memilih di antara pilihan merek yang berbeda dari produk yang sama, namun konsumen juga harus mempertimbangkan masalah yang simpel terkait dengan keputusan pembelian seperti mengenai berapa banyak kandungan karbohidrat dan lemak dalam makanan, apakah membeli produk yang ditanam secara organik atau konvensional, menghindari ikan dengan kandungan merkuri yang tinggi, menerima risiko makanan yang dimodifikasi secara genetik, dan berbagai jenis pertimbangan terkait kesehatan lainnya (Azjen, 2015).

Saat ini makan sehat telah menjadi perhatian utama di antara konsumen yang sadar terhadap persoalan kesehatan tubuh. Meningkatnya jumlah konsumen yang sadar akan kesehatan berpengaruh terhadap jumlah dan kualitas informasi yang dapat dilihat dari menu restoran. Peningkatan konsumsi makanan diluar rumah mungkin memiliki dampak pada kesehatan konsumen. Meskipun tidak melupakan aktivitas fisik, konsumsi kalori yang berlebihan dan nutrisi yang buruk berasal dari konsumsi makanan diluar rumah, terutama di restoran cepat saji. Makanan yang dikonsumsi di restoran, dibandingkan dengan makanan yang disiapkan di rumah, memiliki lebih banyak jumlah kalori, lemak jenuh, kolesterol atau kurang serat, kalsium, dan zat besi (Kim, Ham, Yang, \& Choi, 2013, p. 203).

Makanan sehat telah menjadi tren yang akan memiliki pengaruh besar terhadap strategi perusahaan makanan di tahun mendatang. Tren ini diperkuat oleh fakta bahwa kedepannya konsumen akan memiliki tingkat pendidikan yang lebih baik di seluruh dunia dan pengetahuan yang lebih baik tentang kesehatan dan makan sehat. Selain kesadaran akan manfaat makanan sehat, konsumen juga telah sadar akan akibat dari konsumsi makanan tidak sehat seperti kenaikan jumlah konsumen yang kelebihan berat badan atau obesitas. Menurut data tahun 2008 organisasi WHO, lebih dari 1,4 miliar individu dewasa, berumur 20 tahun keatas mengalami kelebihan berat badan. Di negara Yunani, Amerika Serikat, Italia, Meksiko, Selandia Baru, Chili, dan Inggris Raya memiliki tingkat anak obesitas paling tinggi yang berusia 5-17 tahun di mana persentase anak laki-laki dan perempuan obesitas lebih dari $25 \%$ dari seluruh populasi. 
Negara dengan tingkat obesitas individu dewasa tertinggi adalah Amerika Serikat (33,8\%), Meksiko (30\%), Selandia Baru $(26,5 \%)$ Chili $(25,1 \%)$ dan Australia $(24,6 \%)$ di sebagian besar negara ini, tingkat konsumsi daging termasuk tinggi. Bahkan negaranegara seperti Cina dan India yang tidak peduli dengan obesitas di masa lalu, sekarang menghadapi masalah diabetes dan obesitas. Informasi tentang manfaat kesehatan dapat meningkatkan permintaan makanan sehat dan kesediaan konsumen untuk membeli makanan sehat (Lappo, Bjørndal, Fernandez-Polanco, \& Lem, 2013, p. 4).

Di Indonesia, tren makanan sehat mulai berkembang, didapat dari sumber CNNIndoneisa melalui interview dengan Chief Commercial Expansion Gojek Chaterine Hindra yang memprediksi bahwa makanan sehat seperti salad akan menjadi tren makanan baru di tahun 2019. Hal ini dapat dilihat dari tren data pembelian dan transaksi aplikasi gofood (CNN Indonesia, 2019). Ditengarai, pola pembelian makanan seperti ini muncul karena saat ini warga Indonesia sudah mulai sadar dan perduli akan dampak kesehatan yang diakibatkan oleh makanan seperti obesitas, diabetes, dan penyakit kardiovaskuler (Priherdityo, 2019).

Terkait tren pembelian makanan, faktor kesehatan merupakan faktor yang paling dipertimbangkan konsumen sebelum melakukan pembelian. Fakta ini juga telah mulai disadari oleh para pengusaha di bidang makanan. Untuk dapat tetap bersaing maka para pengusaha di bidang makanan ini harus mulai mempelajari faktor yang dapat membangkitkan minat beli dari konsumen (Mehmeti \& Xhoxhi, 2014). Di dalam penelitian Mehmeti dan Xhoxhi (2014), menjelaskan bahwa di masa depan ada beberapa faktor yang akan menjadi pertimbangan konsumen dalam memilih jenis makanan antara lain:

1. Health: untuk menjadi lebih sehat, mengambil langkah-langkah untuk hidup sehat setiap hari.

2. Convenience: penyajian yang cepat, menghemat waktu.

3. Natural and Organic foods: konsumen yang sadar dan perduli dengan kesejahteraan lingkungan.

4. Pleasure: makanan premium, kenikmatan, nyaman (p. 395).

Dalam penelitiannya, Ajzen (1985) mengemukakan theory of planned behavior, yang merupakan model perpanjangan dari theory of reasoned action, yang diadopsi sebagai kerangka teoritis untuk menciptakan model theory of planned behavior. Ide dasar theory of reasoned action, awalnya dikembangkan oleh Ajzen dan Fishbein (1980), bahwa perilaku/ tindakan seseorang dipengaruhi oleh intention, yang terdiri dari attitude dan subjective norm (Ajzen, 1985).

Theory of planned behavior menggabungkan semua komponen di atas termasuk faktor lain yaitu perceived behavior control, alasan penambahan variabel ini karena perceived behavior control menjelaskan bahwa konsumen dipengaruhi oleh bagaimana konsumen mempersepsikan tingkat kesulitan atau kemudahan untuk melakukan sebuah perilaku/tindakan. Theory of planned behavior didasarkan pada asumsi jika konsumen biasanya akan bertingkah laku sesuai dengan pertimbangan akal sehat serta mengambil informasi yang ada mengenai akibat dari tindankan yang akan dilakukan. Theory of planned behavior membedakan antara tiga jenis belief yaitu behavioral belief, normative belief, dan control belief, dimana hal tersebut terkait dengan konstruksi attitude, subjective norm, dan perceived behavior control (Ajzen, 1985, p. 32). Faktor-faktor yang berpengaruh terhadap purchase intention adalah attitude, subjective norm, dan perceived behavioral control. Berdasarkan paparan di atas, dalam penelitian Alam \& Sayuti (2011), Ajzen (2015) dan Shin \& Hancer (2016) menjabarkan bahwa variabel attitude, subjective norm, dan perceived behavior control berpengaruh terhadap purchase intention seperti dalam theory of planned behavior oleh Ajzen (1985).

Attitude sebagai kecenderungan psikologis yang diekspresikan konsumen dengan cara mengevaluasi hal-hal yang disukai maupun tidak disukai. Variabel pertama yang memiliki pengaruh terhadap purchase intention adalah attitude yang mengacu pada sejauh mana individu memiliki penilaian yang menguntungkan atau penilaian yang tidak menguntungkan dari perilaku atau tindakan yang bersangkutan (Al-Nahdi, et al., 2015). Penelitian mengenai minat beli konsumen makanan Halal di Malaysia menyatakan bahwa attitude memiliki hubungan yang positif dan signifikan terhadap purchase intention makanan di Malaysia, individu yang memiliki attitude positif akan memiliki purchase intention lebih besar (Alam \& Sayuti, 2011).

Dalam theory of planned behavior juga dijelaskan mengenai pengaruh dari subjective norm terhadap purchase intention dan purchase decision bahkan dapat dipengaruhi oleh individu lain. Subjective norm adalah tekanan sosial yang dirasakan konsumen untuk terlibat atau tidak terlibat dalam melakukan suatu perilaku atau tindakan, dan merupakan hasil dari bagaimana konsumen merasakan tekanan sosial yang diberikan, persepsi konsumen tentang tekanan sosial yang ditimbulkannya oleh individu lain mempengaruhi pembelian suatu produk. Tekanan sosial ini bisa muncul dari mana saja seperti (teman, saudara, pasangan, anak, kelompok referensi) dalam penelitian 
sebelumnya dikatakan jika subjective norm berpengaruh secara positif dan signifikan terhadap purchase intention makanan (Alam \& Sayuti, 2011).

Perceived behavior control diartikan sebagai sejauh mana konsumen bisa memiliki kendali atas faktor internal maupun external yang membantu atau menghambat konsumen dalam melakukan suatu perilaku atau tindakan (Al-Nahdi, et al., 2015, p. 122). Dari penelitian Al-Nahdi, et al. (2015) juga diketahui bahwa perceived behavior control berpengaruh positif terhadap purchase intention makanan Halal di Malaysia (Alam \& Sayuti, 2011).

Bisnis makanan sehat yang pada saat penelitian ini dilakukan sedang berkembang pesat di Surabaya bernama Crunchaus. Pada pertengahan tahun 2019, Crunchaus telah berhasil membuka 10 outlet di Indoneisa tepatnya 4 outlet di Jakarta dan 6 outlet di Surabaya sejak 2018. Dalam interview singkat yang dilakukan oleh penulis dengan salah satu manajer yang mengelola media sosial Crunchaus Surabaya mengatakan visi dan misi dari perusahaan Crunchaus adalah menyediakan makanan yang natural, sehat dan enak. Target pasar yang berusaha diraih adalah konsumen yang sudah memiliki pengetahuan akan pentingnya makanan sehat yang alami dan nikmat untuk disantap. Nama Crunchaus membuat semua konsumen senang jika mendengarkan nama Crunchaus itu sendiri, hal ini dikarenakan kesan kesegaran makanan yang didominasi sayuran yang ketika digigit masih crunchy, sebagai pertanda bahwa makanan yang ditawarkan selalu dijaga kesegarannya (Wawancara pribadi, Maret 19, 2019).

Penelitian ini merupakan penelitian replikasi model dari penelitian yang berjudul Applying the Theory of Planned Behavior (TPB) in halal food purchasing (Alam \& Sayuti, 2011). Berdasarkan uraian di atas, penelitian ini ingin mengetahui pengaruh dari attitude, subjective norm dan perceived behavior control terhadap purchase intention makanan sehat di Crunchaus Surabaya. Oleh sebab itu, rumusan masalah dari penelitian ini adalah:

1. Apakah attitude berpengaruh positif dan signifikan terhadap purchase intention makanan sehat di Crunchaus Surabaya?

2. Apakah subjective norm berpengaruh positif dan signifikan terhadap purchase intention makanan sehat di Crunchaus Surabaya?

3. Apakah perceived behavior control berpengaruh positif dan signifikan terhadap purchase intention makanan sehat di Crunchaus Surabaya?

4. Variabel manakah diantara (attitude, subjective norm, dan perceived behavior control) yang memiliki pengaruh paling dominan terhadap purchase intention makanan sehat di Crunchaus Surabaya?
5. Apakah variabel attitude, subjective norm dan perceived behavior control berpengaruh secara simultan terhadap purchase intention makanan sehat di Crunchaus Surabaya.

\section{TINJAUAN PUSTAKA}

\section{Makanan Sehat}

Definisi makanan sehat menurut Ogden (2011) adalah makanan yang memiliki keseimbangan gizi, mengandung serat dan zat-zat yang diperlukan tubuh untuk kelangsungan hidup. Menu makanan yang sehat kaya akan unsur zat gizi seperti karbohidrat, protein, mineral, vitamin, dan sedikit lemak tak jenuh seperti:

1. Fruit and Vegetables: Beragam jenis buah dan sayuran dianjurkan untuk dikonsumsi sebanyak 5 porsi atau lebih dalam 1 hari.

2. Carbohydrate: Beragam jenis karbohidrat yang kompleks seharusnya lebih banyak dikonsumsi, seperti (kentang, roti, umbi) dan direkomendasikan yang memiliki kandungan serat yang tinggi.

3. Meat: Beragam jenis daging, mulai dari sapi, ikan, ayam yang merupakan daging yang paling sering untuk dikonsumsi, direkomendasikan untuk mengkonsumsi varian daging yang rendah lemak.

4. Milk: Susu direkomendasikan untuk diminum secara tidak berlebihan dan direkomendasikan untuk mengkonsumsi varian yang rendah lemak.

5. Fat and sugary food: Makanan yang mengandung lemak jenuh, gula, gorengan, minuman bersoda, dan permen dianjurkan untuk tidak sering dikonsumsi dan jika dikonsumsi disarankan untuk sedikit mungkin.

\section{Theory of Planned Behavior}

Untuk menyelidiki perilaku atau tindakan konsumen dalam membeli makanan lokal, theory of planned behavior merupakan model perpanjangan dari theory of reasoned action, theory of reasoned action diadopsi sebagai kerangka teoritis dalam penelitian ini. Ide dasar theory of reasoned action, awalnya dikembangkan oleh Ajzen dan Fishbein bahwa perilaku atau tindakan individu dipengaruhi oleh attitude dan subjective norm melalui intention (Shin \& Hancer, 2016, p. 2).

Theory of planned behavior menggabungkan semua komponen di atas termasuk faktor lain yaitu perceived behavior control, alasan penambahan variabel ini karena perceived behavior control menjelaskan bahwa konsumen mempersepsikan tingkat kesulitan atau kemudahan untuk melakukan sebuah perilaku 
atau tindakan. Theory of planned behavior didasarkan dengan asumsi jika konsumen biasanya akan bertingkah laku sejalan dengan pertimbangan akal sehat serta mengambil informasi yang ada mengenai akibat dari tindankan yang akan dilakukan. Theory of planned behavior membedakan antara tiga jenis belief yaitu, behavioral belief normative belief, dan control belief, dimana hal tersebut terkait dengan konstruksi attitude, subjective norm, dan perceived behavior control (Ajzen, 1985, p. 32).

\section{Attitude}

Attitude merupakan salah satu faktor psikologis yang mempengaruhi perilaku atau tindakan konsumen dalam membeli suatu barang atau jasa. Attitude adalah evaluasi, perasaan, dan kecenderungan konsumen terhadap suatu objek atau benda yang relatif konsisten. Menurut (Bagher, Salati, \& Ghaffari, 2018, p. 11), Attitude terhadap produk makanan dapat di indentifikasi melalui indikator-indikator sebagai berikut:

1. Membeli makanan sehat merupakan ide yang bagus.

2. Membeli makanan sehat merupakan pilihan yang bijak.

3. Konsumen suka dengan ide membeli makanan sehat.

4. Makanan sehat itu menyenangkan.

5. Makanan sehat bagus untuk kesehatan.

6. Ketersediaan makanan sehat sangat penting untuk saya.

7. Makanan sehat memiliki harga yang tinggi.

8. Makanan sehat memiliki kualitas lebih tinggi.

\section{Subjective Norm}

Subjective norm merupakan pandangan konsumen mengenai perilaku atau tindakan yang dipengaruhi oleh individu lain, konsumen akan melakukan perilaku atau tindakan tertentu jika individu yang dianggap penting oleh konsumen menyetujui perilaku atau tindakan tersebut (Shin \& Hancer, 2016, p. 3). Berikut ini adalah beberapa indikator yang dianggap dapat mempengaruhi konsumen dalam memilih makanan menurut Blackwell, et al. (2012)

1. The Spouse's Influence:

2. The parents Influence:

3. The Friends' Influence:

4. The Reference Group :

5. The child influence:

\section{Perceived Behavior Control}

Perceived behavior control menunjukkan kemampuan konsumen untuk mengatasi kendala dalam melakukan suatu perilaku atau tindakan Indikator untuk mengukur Perceived Behavior Control terhadap menurut Bagher, Salati, \& Ghaffari (2018):

1. Kendali atas pengambilan keputusan pembelian sepenuhnya berada ditangan konsumen.

2. Konsumen memiliki cukup dana untuk membeli produk yang diinginkan.

3. Konsumen memiliki waktu untuk membeli produk yang diinginkan.

\section{Purchase Intention}

Intention adalah tanda dan indikasi kesediaan individu untuk melakukan suatu perilaku atau tindakan, dan merupakan penghubung langsung perilaku, Intention adalah variabel terikat yang diprediksi oleh variabel bebas yaitu attitude, subjective norm dan perceived behavior control, intention bervariasi dari waktu ke waktu, dan dengan berjalannya waktu, semakin rendah hubungan antara intention dan perilaku. Dalam Ferdinand (2006), minat beli diidentifikasi melalui indikator-indikator sebagai berikut:

1. Minat transaksional

2. Minat refrensial

3. Minat preferensial

4. Minat eksploratif

\section{Pengaruh Attitude terhadap Purchase Intention}

Dalam penelitian Alam dan Sayuti (2011) dinyatakan bahwa ada hubungan yang signifikan dan positif antara attitude dan purchase intention produk makanan halal. Penelitian yang dilakukan Alam dan Sayuti menunjukkan bahwa model theory of planned behavior bisa menjelaskan 29,1 persen dari varian purchase intention produk halal. Attitude dianggap sebagai elemen penting dalam mempengaruhi purchase intention produk halal, karena orang-orang yang memiliki attitude positif tampaknya memiliki purchase intention produk halal lebih besar. (Alam \& Sayuti, 2011, p. 16)

Temuan ini memperkuat teori Ajzen yaitu bahwa attitude dapat digambarkan sebagai elemen penting dalam memprediksi dan menggambarkan perilaku/ tindakan manusia. Hasil penelitian serupa didapati oleh Jeger, Ham, \& Leko (2014) yang juga menunjukkan bahwa attitude berpengaruh positif terhadap purchase intention konsumen, khususnya produk makanan sehat. Hal ini berarti bahwa attitude yang dimiliki konsumen terhadap produk makanan akan meningkatkan purchase intention konsumen terhadap produk tersebut. Hal ini disebabkan karena attitude mencerminkan kesadaran konsumen akan perlunya mengkonsumsi makanan sehat serta pengetahuan konsumen seputar produk makanan. 
Berdasarkan paparan penelitian terdahulu maka hipotesis yang disusun dalam penelitian ini terkait pengaruh dari attitude terhadap purchase intention adalah:

H1: Attitude berpengaruh positif dan signifikan terhadap purchase intention konsumen.

\section{Pengaruh Subjective Norm terhadap Purchase Intention}

Studi sebelumnya menunjukkan bahwa subjecttive norm sebagai predikator intention, hubungan yang positif antara subjective norm dan intention dapat dipengaruhi oleh faktor-faktor eksternal seperti kelompok referensi dan keluarga. Faktor eksternal lainnya seperti teman, kolega, dan istri, telah ditemukan mempengaruhi pengambilan keputusan hingga $45 \%$ dan faktor sosial dan budaya, yang ditentukan oleh agama, kekerabatan, dan hubungan sosial, memainkan peran penting dalam purchase intention. Konsumen sering dipengaruhi oleh masukan teman, faktor sosial memainkan peran penting dan bahwa subjective norm memengaruhi purchase intention (Al-Nahdi, et al., 2015, p. 122).

Penelitian lain menemukan subjective norm secara positif terkait dengan intention. Dalam budaya yang lebih individualis seperti budaya barat, konsumen memandang dirinya tidak bergantung dengan kelompok dan memprioritaskan tujuan pribadi dari pada tujuan bersama, yang akan mementingkan keperluan pribadi lebih tinggi dibandingkan norma sosial dalam melakukan suatu perilaku/tindakan. Di sisi lain, dalam budaya kolektif seperti budaya Muslim, konsumen cenderung menganggap dirinya saling bergantung dengan kelompok dan cenderung berjuang untuk tujuan kelompok dari pada tujuan pribadi (Alam \& Sayuti, 2011).

Berdasarkan hasil yang diperoleh dari penelitian terdahulu maka hipotesis yang disusun dalam penelitian ini terkait pengaruh dari subjective norm terhadap purchase intention adalah:

$\mathrm{H} 2$ : Subjective norm berpengaruh positif dan signifikan terhadap purchase intention konsumen.

\section{Pengaruh Perceived Behavior Control terhadap Purchase Intention}

Dalam penelitian yang dilakukan oleh Alam \& Sayuti (2011) menemukan bahwa perceived behavior control berpengaruh positif terhadap purchase intention makanan halal. Pada dasarnya variabel perceived behavior control mencerminkan proses pengambilan keputusan pembelian yang sepenuhnya berada di tangan konsumen. Hal inilah yang membuat variabel ini berdampak positif terhadap purchase intention konsumen. Jika konsumen yakin bahwa keputusan berada di tangan konsumen itu sendiri, maka semakin tinggi pula purchase intention yang ditimbulkan dari kendali atas keputusan tersebut. Di penelitian sebelumnya dikatakan jika perceived behavior control merupakan predikator purchase intention (Al-Nahdi, et al., 2015).

Berdasarkan hasil yang diperoleh dari penelitian terdahulu maka hipotesis yang disusun dalam penelitian ini terkait pengaruh dari perceived behavior control terhadap purchase intention adalah:

H3: Perceived behavior control berpengaruh positif dan signifikan terhadap purchase intention konsumen.

Dalam penelitian yang dilakukan oleh Alam \& Sayuti (2011), diperoleh hasil bahwa dari antara variabel indpenden attitude, subjective norm, dan perceived behavior control, yang memiliki pengaruh paling dominan adalah attitude. Oleh karena itu hipotesis yang disusun dalam penelitian ini adalah (p.16):

H4: Variabel attitude memiliki pengaruh paling dominan terhadap purchase intention.

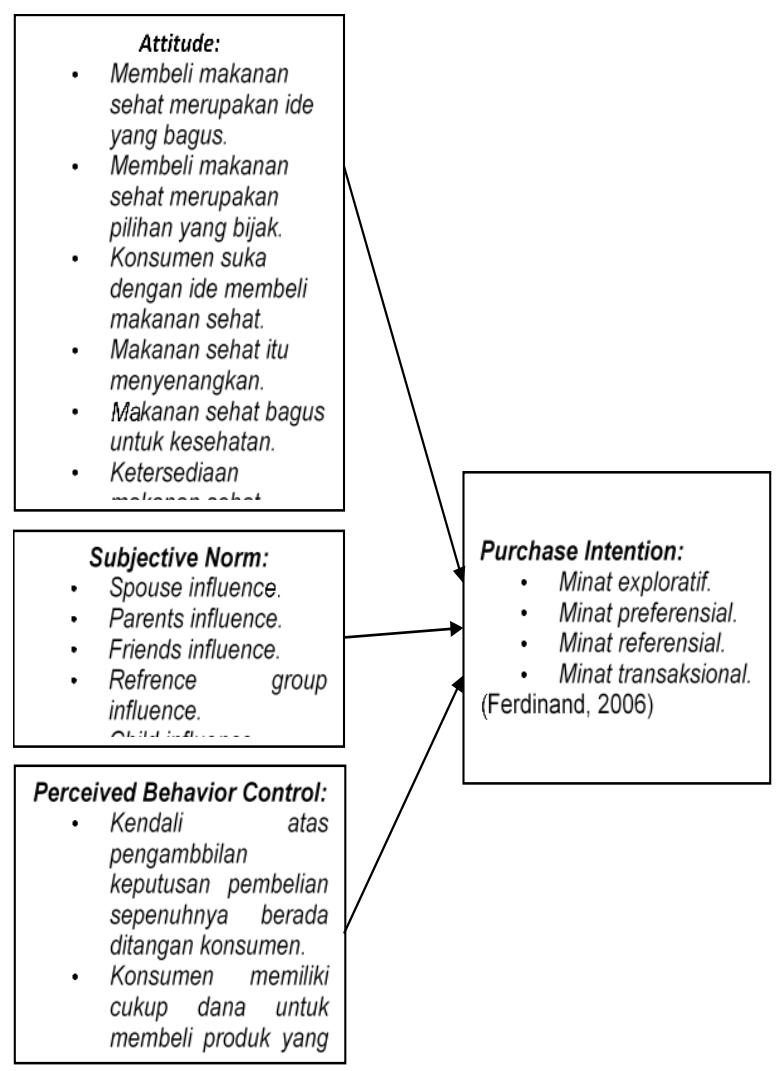

Gambar 1. Kerangka Pemikiran 


\section{METODE PENELITIAN}

Untuk mengetahui pengaruh dari attitude, subjecttive norm, dan perceived behavior control terhadap purchase intention Crunchaus Surabaya, maka penulis mengambil jenis penelitian kuantitatif, penelitian kuantitatif menggunakan data yang diukur dalam suatu skala numerik atau angka.

Populasi dalam penelitian ini adalah seluruh masyarakat yang mengetahui tentang Crunchaus di Surabaya. Untuk mengurangi bias, penulis perlu menetapkan syarat elemen terlebih dahulu. Teknik pengambilan sampel yang digunakan adalah judgemental sampling. Sebelum pemilihan sampel dan pengambilan data dilakukan, syarat harus dipenuhi. Bila tidak, maka tidak boleh dipilih sebagai responden (Ferdinand, 2006). Karakteristik anggota sampel yang dimaksud adalah:

1. Responden berusia minimal 17 tahun keatas.

2. Responden mengetahui Crunchaus Surabaya.

Metode pengumpulan data yang digunakan dalam penelitian ini adalah metode survei yang merupakan metode pengumpulan data primer dengan memberikan pertanyaanpertanyaan kepada responden individu, dimana instrumen yang digunakan adalah kuesioner (Sugiyono, 2016). Data dikumpulkan dengan menggunakan kuesioner dan diukur dengan menggunakan skala likert. Skala likert digunakan untuk mengukur sikap, pendapat dan persepsi seseorang atau sekelompok orang tentang fenomena sosial yang telah ditetapkan oleh peneliti (Sugiyono, 2016). Metode distribusi kuesioner yang digunakan oleh penulis yaitu metode kuesioner secara online dengan bantuan aplikasi media sosial dan mengedarkan kuesioner langsung kepada responden (offline). Penulis membagikan 205 kuesioner untuk mengantisipasi terjadinya kesalahan atau error. Jumlah sampel yang dapat digunakan adalah sebanyak 201 responden.

Teknik analisa yang digunakan penelitian ini adalah analisis kuantitatif deskriptif dengan menggunakan rumus-rumus statistik. (Sugiyono, 2016) Untuk menjawab rumusan masalah, data yang diperoleh dianalisa menggunakan Statistical Product and Service Solutions (SPSS). Dalam penelitian ini, digunakan Analisis Regresi Linear Berganda dimana sebagi variabel independen adalah 3 indikator yaitu Attitude, Subjective Norm dan Percieved Behavior Control. Sedangkan Purchase Intention merupakan variabel dependen dari penelitian ini. Uji $f$ digunakan untuk mengetahui apakah semua variabel bebas yang dimasukkan dalam model memiliki pengaruh secara bersama-sama (simultan) terhadap variabel dependen. Uji t digunakan untuk mengukur seberapa jauh setiap variabel independen memberikan penjelasan yang signifikan terhadap pengaruhnya kepada variabel dependen dengan menggunakan tingkat signifikansi sebesar $5 \%$.

\section{HASIL DAN PEMBAHASAN}

Data penelitian dilakukan dengan menyebarkan kuesioner kepada teman, keluarga dan masyarakat sekitar yang dapat ditemui di tempat-tempat umum seperti pusat perbelanjaan dan outlet Crunchaus Surabaya pada tanggal 20 Mei-11 Juni 2019. Dalam penelitian ini penulis menggunakan dua jenis kuesioner, yaitu kuesioner online yang dibagikan melalui google form dan kuesioner offline berupa kuesioner cetak yang dibagikan secara langsung kepada responden. Sebanyak 201 kuesioner dapat diolah lebih lanjut, dan 4 kuesioner tidak dapat digunakan karena memiliki jawaban yang sama

\section{Profil Responden}

Responden dalam penelitian ini sebagian besar berusia 17-24 tahun yang berjumlah 101 responden dengan persentase sebesar 50,2\%. Jika berdasarkan jenis kelamin, jumlah responden perempuan secara keseluruhan lebih dominan dari pada responden lakilaki dimana responden perempuan berjumlah 112 dengan persentase $55,1 \%$ dan responden laki-laki berjumlah 89 dengan persentase $44,2 \%$.

\section{Analisa Statistik Deskriptif}

Tabel 1. Mean dan Standar Deviasi Variabel Attitude

\begin{tabular}{ccccc}
\hline No. & Pernyataan & Mean & Kategori & Std.Deviasi \\
\hline 1 & X1.1 & 4,01 & Setuju & 0,852 \\
2 & X 1.2 & 3,97 & Setuju & 0,926 \\
3 & X 1.3 & 4,10 & Setuju & 0,846 \\
4 & X 1.4 & 4,01 & Setuju & 0,907 \\
5 & X 1.5 & 3,87 & Setuju & 0,895 \\
6 & X 1.6 & 3,83 & Setuju & $\mathbf{1 , 0 3 0}$ \\
7 & X 1.7 & 3,91 & Setuju & 0,909 \\
8 & X 1.8 & $\mathbf{4 , 1 7}$ & Setuju & 0,799 \\
\hline \multicolumn{7}{c}{ Mean } & $\mathbf{3 , 9 8}$ & Setuju \\
\hline
\end{tabular}

Tabel 2. Mean dan Standar Deviasi Variabel Subjective Norm

\begin{tabular}{|c|c|c|c|c|}
\hline No. & Pernyataan & Mean & Kategori & Std.Deviasi \\
\hline 1 & X 2.1 & 4,09 & Setuju & 0,881 \\
\hline 2 & X 2.2 & 3,75 & Setuju & 1,139 \\
\hline 3 & X 2.3 & 3,56 & Setuju & 1,258 \\
\hline 4 & X 2.4 & 3,43 & Setuju & 1,397 \\
\hline 5 & X 2.5 & 3,95 & Setuju & 0,999 \\
\hline 6 & X 2.6 & 3,91 & Setuju & 1,025 \\
\hline 7 & X 2.7 & 3,83 & Setuju & 1,025 \\
\hline 8 & X 2.8 & 3,93 & Setuju & 0,983 \\
\hline \multicolumn{2}{|c|}{ Mean } & 3,80 & Setuju & \\
\hline
\end{tabular}


Tabel 3. Mean dan Standar Deviasi Variabel Perceived Behavior Control

\begin{tabular}{ccccr}
\hline No. & Pernyataan & Mean & Kategori & Std.Deviasi \\
\hline 1 & X 3.1 & $\mathbf{4 , 1 5}$ & Setuju & 0,856 \\
2 & X 3.2 & 4,10 & Setuju & 0,939 \\
3 & X 3.3 & 3,89 & Setuju & $\mathbf{0 , 9 5 6}$ \\
\hline \multicolumn{2}{c}{ Mean } & $\mathbf{4 , 0 4}$ & Setuju & \\
\hline
\end{tabular}

Tabel 4. Mean dan Standar Deviasi Variabel Purchase Intention

\begin{tabular}{ccccc}
\hline No. & Pernyataan & Mean & Kategori & Std.Deviasi \\
\hline 1 & Y.1.1 & 3,97 & Setuju & $\mathbf{0 , 9 0 2}$ \\
2 & Y 1.2 & 4,05 & Setuju & 0,833 \\
3 & Y 1.3 & $\mathbf{4 , 0 7}$ & Setuju & 0,891 \\
4 & Y 1.4 & $\mathbf{4 , 0 7}$ & Setuju & 0,891 \\
\hline & Mean & $\mathbf{4 , 0 4}$ & Setuju & \\
\hline
\end{tabular}

\section{Koefisien Detreminasi $\left(\mathbf{R}^{2}\right)$}

Uji ini dilakukan untuk mengetahui sejauh mana kemampuan semua variabel bebas dalam menjelaskan variasi variabel terikat.

Tabel 5. Hasil Koefisien Determinasi $\left(\mathrm{R}^{2}\right)$

\begin{tabular}{cccc}
\hline Model & $\mathrm{R}$ & $\mathrm{R}$ Square & Ajusted $\mathrm{R}$ Square \\
\hline 1 & 0,704 & 0,495 & $\mathbf{0 , 4 8 8}$ \\
\hline
\end{tabular}

Dapat dilihat pada tabel 5. bahwa nilai Ajusted $\mathrm{R}^{2}$ menunjukkan angka 0,488 yang dapat diartikan $48,8 \%$ variabel purchase intention dapat diwakili oleh variabel yang dianalisa dalam model, sisanya 51,2\% diwakili oleh variabel lain diluar penelitian ini. Dengan kata lain, persentase kemampuan attitude, subjective norm, dan perceived behavior control untuk memprediksi purchase intention makanan sehat di Crunchaus Surabaya hanya sebesar $48,8 \%$.

\section{Uji Kelayakan Model (Uji F)}

Uji ini dilakukan untuk mengetahui bagaimana pengaruh semua variabel bebas terhadap variabel terikat, dasar pengambilan keputusan adalah apabila nilai signifikan $<0,05$ dan $\mathrm{f}$ hitung $>\mathrm{f}$ tabel $(2,65)$ maka variabel bebas secara bersamaan berpengaruh dengan variabel terikat.

Tabel 6. Hasil Uji F

\begin{tabular}{lll}
\hline Signifikansi & F hitung & Keterangan \\
\hline 0,000 & 65,730 & Berpengaruh simultan \\
\hline
\end{tabular}

Berdasarkan hasil dari table 6. dapat disimpulkan sebagai berikut:

1. Nilai signifikansi $0,000<0,05$ (Berpengaruh simultan).
2. Nilai $F$ hitung $65,730>2,65$ (Berpengaruh simultan).

Sehingga variabel attitude, subjective norm, dan perceived behavior control berpengaruh secara simultan terhadap purchase intention makanan sehat di Crunchaus Surabaya.

Uji T

Uji ini dilakukan untuk mengetahui pengaruh tiap variabel bebas terhadap variabel terikat secara parsial, dasar pengambilan keputusan adalah apabila nilai signifikansi $<0,05$ dan $\mathrm{t}$ hitung $>\mathrm{t}$ tabel $(1,65251)$ maka variabel bebas berpengaruh terhadap variabel terikat secara parsial.

Tabel 7. Hasil Uji t

\begin{tabular}{|c|c|c|c|c|c|}
\hline No & Variabel & $\mathrm{B}$ & Sig. & t hitung & Keterangan \\
\hline 1 & Attitude (X 1.) & .298 & 0,000 & 8,793 & $\begin{array}{l}\text { Berpengaruh } \\
\text { parsial }\end{array}$ \\
\hline 2 & $\begin{array}{l}\text { Subjective } \\
\text { norm (X 2.) }\end{array}$ & .061 & 0,012 & 2,522 & $\begin{array}{l}\text { Berpengaruh } \\
\text { parsial }\end{array}$ \\
\hline 3 & $\begin{array}{l}\text { Perceived } \\
\text { behavior } \\
\text { control (X 3.) }\end{array}$ & .186 & 0,014 & 2,479 & $\begin{array}{l}\text { Berpengaruh } \\
\text { parsial }\end{array}$ \\
\hline & Konstanta & & & 2.849 & \\
\hline
\end{tabular}

Hasil uji f dalam penelitian ini, menyatakan bahwa ketiga variabel yaitu attitude, subjective norm, dan perceived behavior control berpengaruh secara simultan terhadap purchase intention makanan sehat di Crunchaus Surabaya dengan hasil nilai signifikansi lebih kecil dari 0,05, yaitu 0,000 .

$$
Y=2.849+0.298 X 1+0.061 X 2+0.186 X 3
$$

Dari hasil nilai koefisien persamaan variabel attitude, subjective norm dan perceived behavior control pada tabel 4.13. dapat diperoleh nilai sebagai berikut:

1. Nilai koefisien persamaan (X1): 0,298

2. Nilai koefisien persamaan (X2): 0,061

3. Nilai koefisien persamaan (X3): 0,186

\section{Pembahasan}

Pada penelitian yang dilakukan, hasil uji t dalam penelitian ini menunjukkan bahwa variabel bebas yaitu attitude (X1) secara parsial berpengaruh positif dan signifikan terhadap purchase intention makanan sehat di Crunchaus Surabaya, dengan nilai signifikansi kurang dari 0,05 , yaitu 0,000 . 
Hasil ini sejalan dengan penelitian terdahulu yang dilakukan oleh Alam dan Sayuti (2011) menunjukkan bahwa attitude berpengaruh positif dan signifikan terhadap purchase intention makanan halal di Malaysia. Hal ini dikarenakan individu yang memiliki sikap positif terhadap makanan halal akan memiliki niat lebih besar untuk membeli.

Attitude yang positif dan signifikan direfleksikan melalui pernyataan bahwa produk salad yang dijual di Crunchaus Surabaya memiliki kualitas yang tinggi. Dalam konteks penelitian ini membuktikan bahwa responden memiliki evaluasi perasaan dan kecenderungan yang positif terhadap produk salad di Crunchaus Surabaya.

Sehingga hipotesis pertama (H1) "Attitude berpengaruh positif dan signifikan terhadap purchase intention konsumen" dinyatakan diterima.

Pada penelitian yang dilakukan, hasil uji t dalam penelitian ini menunjukkan bahwa variabel bebas subjective norm (X2) secara parsial berpengaruh positif dan signifikan terhadap purchase intention makanan sehat di Crunchaus Surabaya, dengan nilai signifikansi kurang dari 0,05, yaitu 0,014. Hasil ini sejalan dengan penelitian terdahulu yang dilakukan oleh Al-Nahdi et al (2015) menunjukkan bahwa pengaruh subjective norm yang terdiri dari (pasangan, anak, orang tua, kelompok referensi, teman) dapat mempengaruhi purchase intention. Di dalam kuesioner penelitian ini, penulis memberikan pertanyaan kepada responden untuk mengurutkan pilihan seperti (teman, pasangan, orang tua, anak, dan kelompok referensi) mana yang memiliki pengaruh terbesar dalam purchase intention makanan sehat di Crunchaus Surabaya. bahwa teman-teman dari para responden memberikan pengaruh paling besar dalam purchase intention makanan sehat pada masyarakat Surabaya, hal ini juga dapat dilihat dari tingginya poin jawaban yang diberikan terhadap pernyataan di tabel 4.6 yaitu "teman-teman menyarankan saya membeli produk salad di outlet Crunchaus Surabaya". Dalam konteks penelitian ini membuktikan bahwa tekanan sosial yang muncul dari pengaruh teman-teman responden dapat mempengaruhi responden untuk membeli atau tidak membeli produk yang dijual di Crunchaus Surabaya. Sehingga hipotesis kedua (H2) yaitu "Subjective norm berpengaruh positif dan signifikan terhadap purchase intention konsumen" dinyatakan diterima

Pada penelitian yang dilakukan, hasil uji t dalam penelitian ini menunjukkan bahwa variabel bebas perceived behavior control (X3) secara parsial berpengaruh positif terhadap purchase intention makanan sehat di Crunchaus Surabaya, dengan nilai signifikansi kurang dari 0,05, yaitu 0,018. Hasil ini sejalan dengan penelitian terdahulu yang dilakukan oleh Alam dan Sayuti (2011) yang mencerminkan proses pengambilan keputusan pembelian yang sepenuhnya berada di tangan konsumen. Jika konsumen yakin keputusan akhir berada di tangan konsumen itu sendiri maka purchase intention konsumen akan semakin besar. Perceived behavior control yang berpengaruh positif dan signifikan dapat direfleksikan melalui pernyataan bahwa responden memiliki kendali atas keputusan pembelian produk salad di outlet Crunchaus Surabaya. Dalam konteks penelitian ini membuktikan bahwa responden memiliki kemampuan untuk mengkontrol perilaku atau tindakan untuk membeli atau tidak membeli produk yang dijual di Crunchaus Surabaya. Sehingga hipotesis ketiga (H3) yaitu "Perceived behavior control berpengaruh positif dan signifikan terhadap purchase intention konsumen" dinyatakan diterima.

Berdasarkan nilai koefisien persamaan, variabel attitude $(\mathrm{X} 1 .=0,298)$ memiliki nilai terbesar diantara nilai variabel lainnya, hal ini menunjukkan bahwa responden berminat untuk mengkonsumsi produk yang dijual di Crunchaus didorong oleh evaluasi perasaan atau keyakinan yang positif jika mengkonsumsi produk Crunchaus akan menjadi lebih sehat. Oleh karena itu dapat disimpulkan bahwa variabel attitude berpengaruh paling dominan terhadap purchase intention makanan sehat di Crunchaus Surabaya. Hasil ini sejalan dengan penelitian terdahulu yang dilakukan oleh Alam dan Sayuti (2011) dimana variabel attitude lebih dominan dari pada variabel subjective norm dan perceived behavior control. Sehingga hipotesis ke empat (H4) "attitude berpengaruh paling dominan terhadap purchase intention" dinyatakan diterima. Hal ini sejalan dengan hasil penelitian Alam dan Sayuti (2011) menunjukkan bahwa attitude berpengaruh positif dan signifikan terhadap purchase intention makanan halal di Malaysia. Hal ini dikarenakan semakin besar sikap positif seorang individu terhadap makanan yang dibelinya akan semakin besar pula niat individu tersebut untuk membeli produk makanan tersebut.

Hasil uji f menunjukkan bahwa varibel attitude, subjective norm, dan perceived behavior control berpengaruh secara simultan terhadap purchase intention makanan sehat di Crunchaus Surabaya Sehingga hipotesis ke lima (H5) "attitude, subjective norm, dan perceived behavior control berpengaruh secara simultan terhadap purchase intention makanan sehat di Crunchaus Surabaya" dinyatakan diterima.

\section{SIMPULAN DAN SARAN}

\section{Kesimpulan}

1. Pada penelitian ini terbukti bahwa bahwa variabel attitude mempunyai pengaruh positif dan signifykan terhadap purchase intention makanan sehat di Crunchaus Surabaya, sehingga (H1) diterima. Hal 
ini dapat diartikan bahwa responden memiliki evaluasi perasaan atau keyakinan yang positif terhadap produk makanan sehat yang dijual di Crunchaus Surabaya.

2. Pada penelitian ini terbukti bahwa variabel subjective norm mempunyai pengaruh positif dan signifikan terhadap purchase intention makanan sehat di Crunchaus Surabaya, sehingga (H2) diterima. Hal ini dapat di artikan bahwa tekanan sosial yang muncul dapat mempengaruhi responden untuk membeli atau tidak membeli produk makanan sehat yang dijual di Crunchaus Surabaya.

3. Pada penelitian ini terbukti bahwa variabel perceived behavior control mempunyai pengaruh positif dan signifikan terhadap purchase intention makanan sehat di Crunchaus Surabaya, sehingga (H3) diterima. Hal ini dikarenakan keputusan akhir untuk membeli atau tidak membeli produk makanan sehat yang dijual di Crunchaus berada di tangan responden.

4. Pada penelitian ini terbukti bahwa variabel attitude mempunyai pengaruh paling dominan terhadap purchase intention makanan sehat di Crunchaus Surabaya, sehingga (H4) diterima. Hal ini menunjukkan bahwa responden berminat untuk mengkonsumsi produk yang dijual di Crunchaus didorong oleh evaluasi perasaan atau keyakinan yang positif jika mengkonsumsi produk makanan sehat di Crunchaus akan menjadi lebih sehat.

5. Pada penelitian ini terbukti bahwa variabel attitude, subjective norm, dan perceived behavior control berpengaruh secara simultan terhadap purchase intention makanan sehat di Crunchaus Surabaya, sehingga (H5) diterima.

\section{Saran}

1. Bagi Crucnhaus Surabaya atau pelaku industri serupa: Attitude, subjective norm, dan perceived behavior control konsumen terhadap produk makanan sehat berupa salad di Crunchaus Surabaya sangat positif, untuk masa mendatang sebaiknya Crunchaus Surabaya atau pelaku bisnis serupa semakin giat mengedukasi pentingnya makan makanan sehat dengan cara mempromosikan ke masyarakat mengenai manfaat dan kandungan gizi serta pentingnya mengkonsumsi produk makanan alamni, sehat dan aman. Disertai dengan mengadakan kerjasama dengan pemberian potongan pembayaran oleh perusahaan onlne food ordering, hal ini diharapakan meningkatkan penjualan produk makanan sehat.
2. Bagi penelitian selanjutnya.: Model dalam penelitian ini dapat memprediksi purchase intention sebesar 46,6\% sisanya 53,4\% dapat diprediksi oleh variabel lain, untuk penelitian selanjutnya dapat menerapkan penelitian ini pada restoran yang mengusung konsep makanan sehat yang belum pernah diteliti lainnya seperti Greenly, Loving Hut, Omah Jamur, dsb. Penelitian selanjutnya dapat menggunakan variabel 7P dari teori Marketing Mix seperti variabel place, price, promotion dan menambahkan variabel social media marketing untuk melihat efek dari promosi melalui media sosial

\section{DAFTAR REFERENSI}

Ajzen, I. (1985). From Intentions to Actions: A Theory of Planned Behavior. Berlin: Springer Science \& Business Media.

Azjen, I. (2015). Consumer Attitudes and Behavior: The Theory of Planned Behavior Applied to Food Consumption Decision. Rivista di Economia Agraria, 70(2), 122-138.

Ajzen, I \& Fishbein, M. (1980). Understanding Attitudes and Predicting Social Behavior, Englewood-Cluffs, N.J.: Prentice-Hall

Alam, S. S., \& Sayuti, N. M. (2011). Applying The Theory of Planned Behavior (TPB) In Halal Food Purchasing. International Journal of Commerce and Management, 2(1), 8-20.

Al-Nahdi, T. S., Habib, S. A., Bakar, A. H., Bahklah, M. S., Hassan, O., \& Al-Attas, H. A. (2015). The Effect of Attitude, Dimensions of Subjective Norm, And Perceived Behavior Control, On The Intention to Purchase Real Estate in Saudi Arabia. International Journal of Marketing Studies, 7(5), 120-131.

Bagher, A. N., Salati, F., Mohammad, \& Ghaaffari. (2018). Factors Affecting Intention to Purchase Organic Foof Products Among Iranian Consumer. Academy of Marketing Studies Journal, 2(3), 1-23.

Blackwell, R. D., Miniard, P. W., Engel, J. F., DiChing, P., Yasin, N. M., Jooria, H. W. (2012). Consumer Behavior. Singapore: Cengage Learning.

CNNIndonesia. (2019, january 8). Makanan Sehat dan Kopi Diprediksi Bakal Tren di Indonesia. Retrieved from Cnnindonesia.com: https://www. cnnindonesia.com/gaya-hidup/20190108180459262-359357/makanan-sehat-dan-kopi-diprediksi-bakal-tren-di-indonesia

Ferdinand, A., 2006. Metode Penelitian Mananjemen: Pedoman Penelitian untuk Penulisan skripsi, Tesis, dan disertasi Ilmu Manajemen. Semarang: Badan Penerbit Universitas Diponegoro. 
Ferdinand, A. (2014). Metode Penelitian Management Pedoman Penelitian Untuk Penulisan Skripsi Tesis Dan Disertasi Ilmu Management. Semarang: Badan Penerbit Universitas Diponogoro.

Jeger, M., Ham, M., \& Leko, V. (2014). Attitudes Toward Green Food Purchase Among Students: Evidence from Easter Croatia. Researchgate.

Kim, E., Ham, S., Yang, I. S., \& Choi, J. G. (2013). The Roles of Attitude, Subjective Norm, And Perceived Behavioral Control in The Formation of Consumers' Behavioral Intentions to Read Menu Labels in The Restaurant Industry. International Journal of Hospitality Management, 35, 203-213.

Lappo, A., Bjørndal, T., Fernandez-Polanco, J., \& Lem, A. (2013). Consumer trends and prefences in the demand for food. Bergen: International Management of Pelagic Fisheries.

Mehmeti, G., \& Xhoxhi, O. (2014). Future Food Trends. Annals. Food Science and Technology, 15(2), 392-400.
Ogden, J. (2011). The Psychology of Eating from Healthy to Disordered Behavior. Chicester: Wiley-Blackwell.

Priherdityo, E. (2019, september 9). Survei: Masyarakat Indonesia Mulai Sadar Makanan Sehat. Retrieved from Cnnindonesia.com: https://www. cnnindonesia.com/gaya-hidup/20160909050 532255-157172/survei-masyarakat-indonesiamulai-sadar-makanan-sehat

Rachbini, W. (2018). The Relationship of Attitude, Subjective Norm, Perceived Behavioral Control on Halal Food Purchasing Behavior in Jakarta. IOSR Journal of Business and Management, 20(1), 28-37.

Shin, Y. H., \& Hancer, M. (2016). The Role of Attitude, Subjective Norm, Perceived Behavioral Control, And Moral Norm in The Intention to Purchase Local Food Products. Journal of Food Service Business Research, 19(4), 1-14.

Sugiyono. (2016). Metode Penelitian Kuantitatif, Kualitatif dan $R \& D$. Bandung: Alfabeta. 